\title{
How to Promote Medium-Sized Farms to Adopt Environmental Strategy to Achieve Sustainable Production during the COVID-19 Pandemic?
}

\author{
Stanley Y. B. Huang ${ }^{1}\left(\mathbb{D}\right.$, Kuei-Hsien Chen ${ }^{2, *(D)}$ and Yue-Shi Lee ${ }^{3}$ (D) \\ 1 Master Program of Financial Technology, School of Financial Technology, Ming Chuan Unversity, \\ Taipei 111, Taiwan; yanbin@mail.mcu.edu.tw \\ 2 Department of Marketing and Logistics Management, College of Business Management, \\ Chihlee University of Technology, New Taipei 220, Taiwan \\ 3 Department of Computer Science and Information Engineering, Ming Chuan University, \\ Taoyuan City 333, Taiwan; leeys@mail.mcu.edu.tw \\ * Correspondence: khchen@mail.chihlee.edu.tw
}

Citation: Huang, S.Y.B.; Chen, K.-H.; Lee, Y.-S. How to Promote MediumSized Farms to Adopt Environmental Strategy to Achieve Sustainable Production during the COVID-19 Pandemic? Agriculture 2021, 11, 1052. https://doi.org/10.3390/agriculture 11111052

Academic Editor: Piotr Prus

Received: 30 September 2021

Accepted: 20 October 2021

Published: 27 October 2021

Publisher's Note: MDPI stays neutral with regard to jurisdictional claims in published maps and institutional affiliations.

Copyright: (c) 2021 by the authors. Licensee MDPI, Basel, Switzerland. This article is an open access article distributed under the terms and conditions of the Creative Commons Attribution (CC BY) license (https:// creativecommons.org/licenses/by/ $4.0 /)$.

\begin{abstract}
To achieve sustainable production in medium-sized farms, this research proposes a hierarchical linear modeling (HLM) to predict environmental strategy (ES), which is a crucial source of sustainable production. Based on the theory of upper echelons, the present research puts forward that the environmental leadership (EL) of the chief executive officer (CEO) at phase one affects the development of environmental corporate social responsibility (ECSR) adoption, which in turn affects the development of ES adoption over time. The empirical data were obtained through a three-stage sampling method of 90 CEOs and 270 members of senior management teams (SETs) of Taiwanese medium-sized farms, over a period of six months. The research results support that the higher level of CEO EL at phase one results in the development of ECSR adoption, which in turn results in the development of ES adoption. This research opens a new direction for sustainable production by showing how to implement ES through organizational management mechanisms (EL). These findings can fill the gaps in the literature on the sustainable production of farms and can also help these farms to achieve sustainable production by adopting ES.
\end{abstract}

Keywords: environmental corporate social responsibility; environmental leadership; environmental strategy

\section{Introduction}

\subsection{Background}

Contemporary farms should select an environmental strategy (ES) to achieve sustainable production under the pressure of external stakeholders [1,2] because farms can implement ES to realize sustainable production [3-5]. Indeed, the agricultural production process will inevitably consume a substantial number of resources and cause pollution [6]. ES is defined as the extent to which a company adds environmental issues to its development plan to reduce pollution caused by production activities [7]. Therefore, according to the theory of the upper echelons [8], this research adopts a novel model to predict the ES, that is, the environmental leadership (EL), of chief executive officers (CEOs), used as a driver of ES by the medium effect of environmental corporate social responsibility (ECSR). EL means leadership concerning ethical behavior and environmental responsibility [9]. ECSR means the company's responsible policy toward the welfare of multiple stakeholders [10]. The upper echelons theory believes that the features or values of senior managers should significantly influence the company's strategic choice [8], and leadership is an important feature of CEOs [11], thus indicating the relationship between EL and ECSR adoption. 
Past agricultural research in the ES field often used environmental engineering techniques to deal with environmental issues, such as recycling fertilizers [12] or photovoltaic systems [13]. Since environmental engineering technology is no more effective than using ES, this research proposes a new stream that uses a psychometric perspective to deal with environmental issues. In addition, past research has suggested that organizationlevel policies (e.g., organization-level ECSR) may affect individual-level variables (e.g., individual-level ES) [14], but few studies have focused on this hypothesis. To fill this gap, this research adopts the HLM [15] to investigate how EL promotes ECSR growth, which consequently promotes the development of ES adoption at an organizational and individual level. In particular, the perspective of predicting ES from the perspective of multi-level psychometrics is rarely published in related journals in the agricultural field, leading to a serious gap in the investigation of farm organization psychology.

In summary, this research proposes the theoretical framework based on the theory of upper echelons [9] and adopts a HLM to conduct empirical data on 90 CEOs and 270 members of senior management team (SETs) members of Taiwanese medium-sized farms to address how EL can affect ES through ECSR. The incremental contribution of this research is to propose a novel HLM that constructs the key driving factors of ES from a multilevel perspective. This is because previous research is almost an individual-level perspective [16-19]. The research question (RQ) is as follows:

RQ: Can individual-level and organization-level EL influence the adoption of ES through the intermediary effect of individual-level and organization-level ECSR?

\subsection{Literature Review}

\subsubsection{EL and ECSR}

Transformational leadership theory has been regarded as an important driver of employee behavior and company strategy [20-25]. Indeed, transformational leadership has been studied across different disciplines [26-30]. Corporate social responsibility has also been studied across various disciplines [31-35].

EL denotes the transformational leadership toward ethics and environmental responsibility [10]. The theory of upper echelons [9] can be employed to connect these two variables. The theory of upper echelons [9] suggests that the features or values of senior supervisors (e.g., CEOs) will influence the company's preference for strategic attributes, and leadership is a key feature of the CEO [12], thus showing the relationship between EL and ECSR adoption. Indeed, past studies have also put forward similar assumptions that the leadership of the CEO can prompt the company to adopt corporate social responsibility [36-38].

Hypothesis 1. A greater level of EL in phase 1 would lead to the development of ECSR adoption propensity.

\subsubsection{ECSR and ES}

First, ECSR means the company's preference for environmental responsibility, which is determined by the company's senior supervisors Indeed, senior supervisors have the legitimacy to engage in business activities [39], so these senior supervisors can influence the company's strategic choices because of their preferences or values. According to the theory of upper echelons, these preferences or values will affect the company's ES adoption [9]. Finally, since the company with a high-level ECSR pays attention to environmental-related stakeholders, ES is a tool for improving the corporate sustainability and corporate environmental performance that can satisfy the requirements of these stakeholders, thus showing the relationship between ECSR and ES.

Hypothesis 2. More development of ECSR would lead to more development of ES adoption propensity over time. 


\subsubsection{Organization-Level EL and ECSR to ES}

Although EL and ECSR can be analyzed at an individual-level system, previous studies have examined these variables at an organization-level system [40-44]. The social information processing theory also believes that people obtain information from the same workgroup and form the shared and similar atmosphere of EL and ECSR (i.e., organizationlevel EL and ECSR) with other members.

Indeed, the theory of social cognition also confirms the hypothesis that humanlevel systems and environmental-level systems can affect human-level systems at the same time [45]. In other words, organization-level and individual-level EL can influence individual-level ES through the mediating effect of organizational-level and individuallevel ECSR. Previous empirical studies have tested similar hypotheses [46-48].

Based on the above discussion, the present research proposes that the individual-level hypotheses between EL, ECSR, and ES should be the same as organization-level hypotheses between EL, ECSR, and ES. Thus:

Hypothesis 3. Organization-level EL at phase 1 would lead to more development of organizationlevel ECSR.

Hypothesis 4. More development of organization-level ECSR would lead to more development of ES adoption.

\section{Materials and Methods}

The HLM of the present survey describes that the organization-level and the individuallevel EL results in further development at the organization-level and individual-level ECSR, while more developments in the organization-level and individual-level ECSR will lead to more developments in ES over time (Figure 1).

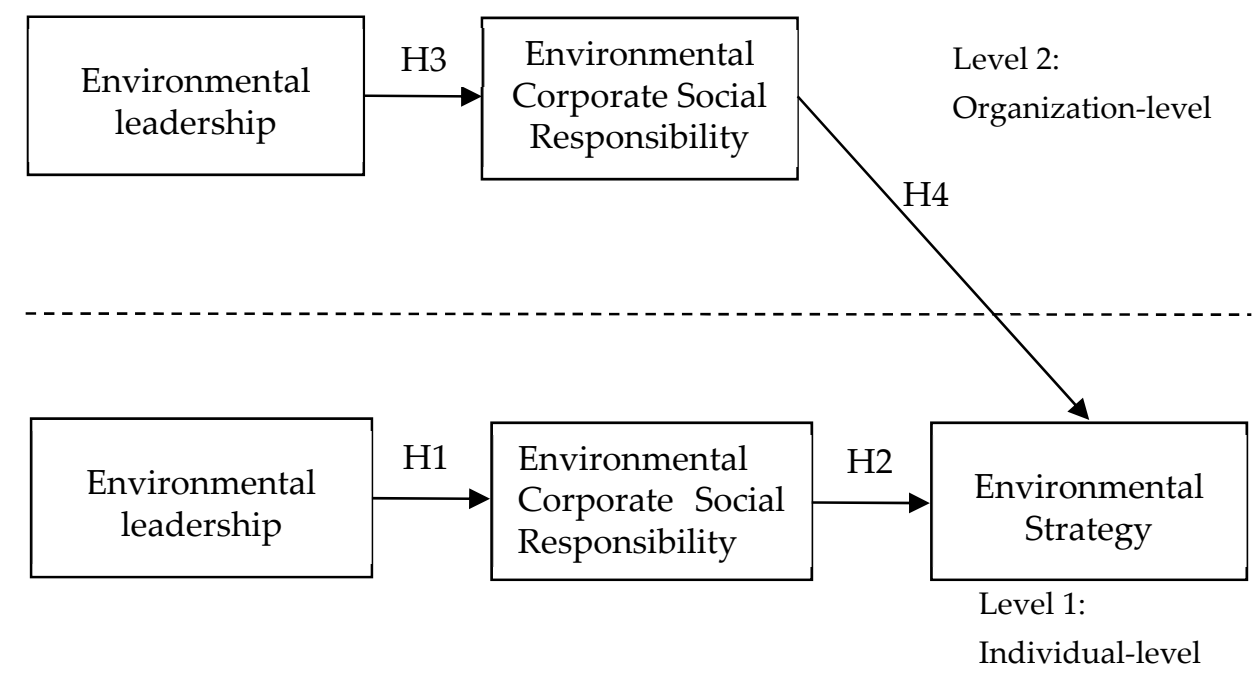

Figure 1. The HLM of this research. Note: $\mathrm{H} 1=$ Hypothesis $1 ; \mathrm{H} 2=$ Hypothesis 2; $\mathrm{H} 3=$ Hypothesis 3; $\mathrm{H} 4=$ Hypothesis 4 .

\subsection{Sampling and Procedures}

To obtain a sampling list of medium-sized farms, we approached several agricultural associations in Taiwan and contacted these medium-sized farms to take part in the survey. The 90 CEOs of these farms were willing to assist in the survey. We asked them to invite three members of their SETs to take part in the survey. We contacted these 90 CEOs and 270 members of their SETs from 90 different farms via email to prevent them from obtaining their questionnaire information.

This survey investigated the 90 CEOs' evaluations on ES in the first phase and the evaluations adopted by 270 members of SETs on the evaluations of the EL and their ECSR. 
Three months after the end of the first phase, we surveyed 90 CEOs' evaluations of ES and 270 members of SETs on the evaluations of ECSR in the second phase. Finally, three months after the end of the second phase, we surveyed the evaluations of 90 CEOs on ES and 270 members of SETs on the evaluations of ECSR in the third phase.

\subsection{Measures}

The present survey adopts the 7-point Likert scale to evaluate the EL, ECSR, and ES. The operational definition for EL, ECSR, and ES is as Table 1. In addition, to confirm whether individual-level EL, ECSR, and ES can be aggregated into the organization-level EL, ECSR, and ES, we adopted James et al.'s [49] $r_{w g(j)}$ to confirm the feasibility.

EL was assessed by Robertson's 12-item scale [10]. ECSR was assessed by 4-item scale of Wei and colleagues [11]. ES was assessed by 5-item scale of Banerjee and colleagues [8].

Table 1. Operational Definitions.

\begin{tabular}{|c|c|}
\hline Variables & Operational Definitions \\
\hline Environmental Leadership & $\begin{array}{l}\text { Leadership toward ethical behavior and environmental } \\
\text { responsibility }\end{array}$ \\
\hline Environmental Social Responsibility & $\begin{array}{l}\text { The company's responsible policy toward multiple } \\
\text { stakeholders' welfare }\end{array}$ \\
\hline Environmental Strategy & $\begin{array}{l}\text { A company adds an environmental concern to its } \\
\text { development plan to reduce pollution caused by } \\
\text { production activities }\end{array}$ \\
\hline
\end{tabular}

\subsection{Model Validation}

The descriptive statistics of EL, ECSR, and ES are as Table 2. We adopted an analysis technique of confirmatory factor to analyze the model fit, average variance extracted (validity), and composite reliability (reliability), which are in line with the suggestions of Fornell and Larcker [50] (please see Table 3).

Table 2. Means, standard deviations, and correlations.

\begin{tabular}{ccccc}
\hline & M & S.D. & EL & ECSR \\
\hline Environmental Leadership & 4.59 & 0.81 & & \\
Environmental Social & 4.79 & 0.80 & 0.41 & \\
$\quad$ Responsibility & 4.51 & 0.82 & 0.31 & 0.39 \\
Environmental Strategy & & \\
\hline
\end{tabular}

Table 3. The analysis results of CFA.

\begin{tabular}{cccc}
\hline Variables & $\mathbf{r}_{\mathbf{w g}(\mathbf{j})}$ & Average Variance Extracted & Composite Reliability \\
\hline EL & 0.81 & 0.57 & 0.89 \\
ECSR & 0.83 & 0.56 & 0.87 \\
ES & 0.82 & 0.59 & 0.88
\end{tabular}

Note: EL = Environmental Leadership; ECSR = Environmental Corporate Social Responsibility; ES = Environmental Strategy. Root Mean Residual = 0.61; Root mean Square Error of Approximation = 0.48; Goodness of Fit $=0.91$; Comparative Fit IndexI = 0.90; Normed Fit Index $=0.90$.

\section{Results}

Since the data structure of this research is nested in multiple farms (the same within the group, but there are differences between the groups), we adopt the HLM [15] for analyzing multilevel framework. The analysis results are demonstrated in Table 4. Individual-level EL at phase 1 would significantly result in the further development of ECSR $(\gamma=0.32$, $p<0.01$ ). This would significantly result in the further development of ES adoption $(\gamma=0.35, p<0.01)$. In other words, a higher level of EL at phase 1 would influence more 
development of ECSR development, which would in turn influence further development of ES adoption over time to support Hypotheses 1 and 2.

The organization-level EL at phase 1 would significantly result in the development of organization-level ECSR $(\gamma=0.41, p<0.01)$, which would significantly influence more development of ES adoption $(\gamma=0.37, p<0.01)$. In other words, a higher level of organizationlevel EL at phase 1 would influence more development of organization-level ECSR. More development of organization-level ECSR would cause more development of ES adoption over time to support hypotheses 3 and 4 .

To verify the intermediary effect of ECSR at the organizational and individual level, this research adopts the chi-squared difference test to analyze three potential models. The first potential model was formed by adding a path from EL to ES in Figure 1, and the positive change of the chi-squared value was $39(p<0.01)$, indicating the significant disadvantage of the fit index. The result shows that the ECSR should be a mediating variable. The second potential model was formed by removing the path from ESCR to ES in the first potential model, and the positive change of chi-squared value was $33(p<0.01)$, indicating a significant poor fit index. The result shows that the ECSR and EL cannot be the antecedents of ES at the same time, and ECSR should be a mediating variable between EL and ES. The third potential model was formed by removing the path from ECSR to ES and adding the path from ECSR to EL in the second potential model. That is, we assume that EL is the mediating variable between ECSR and ES. The positive change of the chi-squared value was $41(p<0.01)$, indicating the significant poor fit index. The result also supports that the ECSR should be a mediating variable. These results support that the EL in the first phase should directly cause more ECSR growth, and more ECSR growth should also cause more ES growth.

Table 4. Results of HLM.

\begin{tabular}{cccc}
\hline Hypothesis & Path & Coefficient & Results \\
\hline H1 & Individual-level EL $\rightarrow$ Individual-level ECSR & $0.32^{* *}$ & H1 is supported \\
H2 & Individual-level EL ECSR $\rightarrow$ Individual-level EL ES & $0.35^{* *}$ & H2 is supported \\
H3 & Organization-level EL $\rightarrow$ Organization-level ECSR & $0.41^{* *}$ & H3 is supported \\
H4 & Organization-level ECSR $\rightarrow$ Individual-level ES & $0.37^{* *}$ & H4 is supported \\
\hline
\end{tabular}

Notes: EL = Environmental Leadership; ECSR = Environmental Corporate Social Responsibility; ES = Environmental Strategy. ${ }^{* *}: p<0.01$.

\section{Discussion}

\subsection{Contribution to Academic}

The empirical results demonstrate that EL at phase 1 would influence the development of ECSR, which would influence more development of ES adoption, supporting Hypotheses 1 and 2. First, these results detect the key antecedents of ES adoption where the connection has not been studied in the past. Second, although ECSR research has received significant attention, the essence of ECSR still requires further extensive investigation [51]. Indeed, this research investigated how the CEO's EL would cause ECSR, which results in the SET's ECSR-specific behavior (e.g., the SET's preference or values for environmental responsibility). In addition, ECSR also affects ES. The link of EL-ECSR-ES opens the black box in different contexts.

In addition to considering the individual-level antecedents of ES, this research also considers the organization-level antecedents to echo the recommendations of previous research [14]. Based on a multilevel perspective, organization-level EL at phase 1 would influence more organization-level ECSR development, and more development of organizationlevel ECSR would influence more development of ES adoption, which suppose Hypotheses 3 and 4. Indeed, the multilevel theory also supports this presumption that environmental variables (e.g., organization-level ECSR) can significantly influence psychological variables (e.g., individual-level ES) [16], but past research has ignored this presumption. Therefore, the present research contributes to the ES literature through individual-level and organization-level mechanisms that EL at phase 1 time would lead to more develop- 
ment of individual-level and organization-level ECSR, as well as more developments at the individual and organizational levels. ECSR would lead to more developments in ES adoption over time, which responds to the call of the researcher in the past to open more black boxes of corporate social responsibility [52].

\subsection{Contribution to Practice}

In the agriculture field, exploring how medium-sized farms can employ ES to improve environmental sustainability is a great benefit to sustainable agricultural production. Indeed, the results of this research show that medium-sized farms can implement ES through the organization management mechanism (EL of CEOs) and the ECSR adoption. In addition, ECSR has been recognized as a source of corporate sustainability [53], so ECSR may also be an important source of sustainable agricultural production. Finally, these human resource managers should pay attention to the key antecedent of green management (e.g., EL, and ECSR), and should keep in mind that maximizing these green management behaviors and constructing a green work environment are the key driving factors of sustainable production, such as green staff meetings, green activities, and the display of green vision and values of companies. Finally, to effectively enhance the CEO's EL ability, human resource managers should regard EL education and training as an important investment for the enterprise, because EL is a key driving factor for the development of ES.

\subsection{Limitations}

The present researcher believes that ECSR is a key intermediary variable used to transform the CEO's EL into the company's ES adoption, but other variables may have similar effects in different contexts. Next, although this research puts forward EL as an important driver of ES, other variables may have similar effects, such as transformational leadership [54], responsible leadership [55], and environmentally specific leadership [48]. Finally, the empirical data are limited to Taiwan, which may affect the generalization of the theoretical model.

\section{Conclusions}

The present research proposes the HLM to prove that the CEO's EL would lead to the development of ECSR, which in turn would lead to the development of ES adoption. The HLM has important contributions to EL, ECSR, and ES literature and can guide sustainable agricultural production to agricultural production companies. Indeed, past studies have rarely adopted this perspective to discuss why farms adopt ES and this research constructs the milestone that proposes EL and ECSR as antecedents of ES, which provides significant contribution for literature on sustainable production and guides the implementation of ES on farms. The research has also promoted the practical and academic development of ES and has filled the gaps in the multi-level framework and cross-sectional research of the previous literature. Finally, the other incremental contribution of this research is to verify that ECSR and ES can be changed over time to support the growth perspective. Indeed, past research has ignored this gap and regarded these constructs as cross-section structures, so this research opens a new way of thinking in behavioral science research by the HLM.

Further study should test the framework of the present survey under different backgrounds to explore other intermediary variables. Next, this research confirms that EL is a key antecedent of ES, and further study should explore other important leadership styles in different contexts. Next, further research should collect different data in different countries to verify the external validity of the theoretical model, because there is no strong evidence that the Taiwanese sample is the same as other countries. Finally, further study should employ experimental designs to verify the empirical results to reduce bias.

Author Contributions: Conceptualization, S.Y.B.H.; Data curation, K.-H.C.; Formal analysis, K.-H.C.; Funding acquisition, Y.-S.L.; Investigation, K.-H.C.; Project administration, S.Y.B.H.; Software, Y.-S.L.; Supervision, S.Y.B.H.; Validation, Y.-S.L.; Visualization, Y.-S.L.; Writing-original draft, S.Y.B.H.; Writingreview \& editing, K.-H.C. All authors have read and agreed to the published version of the manuscript. 
Funding: This research received no external funding.

Institutional Review Board Statement: Not applicable.

Informed Consent Statement: Not applicable.

Data Availability Statement: Not applicable.

Conflicts of Interest: The authors declare no conflict of interest.

\section{References}

1. Lehtonen, H.; Palosuo, T.; Korhonen, P.; Liu, X. Higher crop yield levels in the North Savo region-Means and challenges indicated by farmers and their close stakeholders. Agriculture 2018, 8, 93. [CrossRef]

2. Mantino, F.; Forcina, B. Market, policies and local governance as drivers of environmental public benefits: The case of the localised processed tomato in northern Italy. Agriculture 2018, 8, 34. [CrossRef]

3. Liu, H.-T. The Influence of Public Servants' Perceived Formalism and Organizational Environmental Strategy on Green Behavior in the Workplace. Sustainability 2021, 13, 11020. [CrossRef]

4. Pańka, D.; Jeske, M.; Łukanowski, A.; Prus, P.; Szwarc, K.; Muhire, J. Achieving the European green "deal" of sustainable grass forage production and landscaping using fungal endophytes. Agriculture 2021, 11, 390. [CrossRef]

5. Xu, J.; Zhang, Z.; Zhang, X.; Ishfaq, M.; Zhong, J.; Li, W.; Zhang, F.; Li, X. Green food development in China: Experiences and challenges. Agriculture 2020, 10, 614. [CrossRef]

6. Crippa, M.; Solazzo, E.; Guizzardi, D.; Monforti-Ferrario, F.; Tubiello, F.N.; Leip, A. Food systems are responsible for a third of global anthropogenic GHG emissions. Nat. Food 2021, 2, 198-209. [CrossRef]

7. Banerjee, S.B.; Iyer, E.S.; Kashyap, R.K. Corporate environmentalism: Antecedents and influence of industry type. J. Mark. 2003, 67, 106-122. [CrossRef]

8. Hambrick, D.C. Upper echelons theory: An update. Acad. Manag. Rev. 2007, 32, 334-343. [CrossRef]

9. Robertson, J.L. The nature, measurement and nomological network of environmentally specific transformational leadership. J. Bus. Ethics 2018, 151, 961-965. [CrossRef]

10. Wei, Z.; Shen, H.; Zhou, K.Z.; Li, J.J. How does environmental corporate social responsibility matter in a dysfunctional institutional environment? Evidence from China. J. Bus. Ethics 2017, 140, 209-223. [CrossRef]

11. Liu, D.; Fisher, G.; Chen, G. CEO attributes and firm performance: A sequential mediation process model. Acad. Manag. Ann. 2018, 12, 789-816. [CrossRef]

12. Dharminder; Singh, R.K.; Kumar, V.; Pramanick, B.; Alsanie, W.F.; Gaber, A.; Hossain, A. The use of municipal solid waste compost in combination with proper irrigation scheduling influences the productivity, microbial activity and water use efficiency of direct seeded rice. Agriculture 2021, 11, 941. [CrossRef]

13. Khatib, T.; Qalalweh, S.; Ameerah, R.; Warad, I. An efficient method for water treatment of artificial ponds in jordan valley based on photovoltaic pumping system. Agriculture 2019, 9, 151. [CrossRef]

14. Fritsche, I.; Barth, M.; Jugert, P.; Masson, T.; Reese, G. Collective climate action (SIMPEA). Psychol. Rev. 2018, 125, 245-269. [CrossRef] [PubMed]

15. Raudenbush, S.W.; Bryk, A.S. Hierarchical Linear Models: Applications and Data Analysis Methods; Sage: Thousand Oaks, CA, USA, 2002.

16. Suska, M. Environmental Corporate Social Responsibility (ECSR) on the Example of Polish Champion Oil, Gas and Mining Companies. Sustainability 2021, 13, 6179. [CrossRef]

17. Myeni, L.; Moeletsi, M.E. Factors determining the adoption of strategies used by smallholder farmers to cope with climate variability in the eastern free state, South Africa. Agriculture 2020, 10, 410. [CrossRef]

18. Ullah, A.; Mahmood, N.; Zeb, A.; Kächele, H. Factors determining farmers' access to and sources of credit: Evidence from the rain-fed zone of Pakistan. Agriculture 2020, 10, 586. [CrossRef]

19. Wierzbiński, B.; Surmacz, T.; Kuźniar, W.; Witek, L. The role of the ecological awareness and the influence on food preferences in shaping pro-ecological behavior of young consumers. Agriculture 2021, 11, 345. [CrossRef]

20. Huang, S.; Fei, Y.-M.; Lee, Y.-S. Predicting job burnout and its antecedents: Evidence from financial information technology firms. Sustainability 2021, 13, 4680. [CrossRef]

21. Huang, S.; Ting, C.-W.; Li, M.-W. The effects of green transformational leadership on adoption of environmentally proactive strategies: The mediating role of green engagement. Sustainability 2021, 13, 3366. [CrossRef]

22. Wu, Q.; Cherian, J.; Samad, S.; Comite, U.; Hu, H.; Gunnlaugsson, S.B.; Oláh, J.; Sial, M.S. The role of CSR and ethical leadership to shape employees' pro-environmental behavior in the era of industry 4.0. A case of the banking sector. Sustainability 2021, 13, 9773. [CrossRef]

23. Freire, C.; Gonçalves, J. The relationship between responsible leadership and organizational citizenship behavior in the hospitality industry. Sustainability 2021, 13, 4705. [CrossRef]

24. Nor-Aishah, H.; Ahmad, N.H.; Thurasamy, R. Entrepreneurial leadership and sustainable performance of manufacturing SMEs in Malaysia: The contingent role of entrepreneurial bricolage. Sustainability 2020, 12, 3100. [CrossRef]

25. Barling, J.; Loughlin, C.; Kelloway, E.K. Development and test of a model linking safety-specific transformational leadership and occupational safety. J. Appl. Psychol. 2002, 87, 488-496. [CrossRef] 
26. Bazzoli, A.; Curcuruto, M.; Morgan, J.; Brondino, M.; Pasini, M. Speaking up about workplace safety: An experimental study on safety leadership. Sustainability 2020, 12, 7458. [CrossRef]

27. Beauchamp, M.R.; Barling, J.; Li, Z.; Morton, K.L.; Keith, S.E.; Zumbo, B.D. Development and psychometric properties of the transformational teaching questionnaire. J. Health Psychol. 2010, 15, 1123-1134. [CrossRef]

28. Morton, K.L.; Barling, J.; Rhodes, R.E.; Mâsse, L.C.; Zumbo, B.D.; Beauchamp, M.R. The application of trans-formational leadership theory to parenting: Questionnaire development and implications for adolescent self-regulatory efficacy and life satisfaction. J. Sport Exerc. Psychol. 2011, 33, 688-709. [CrossRef]

29. Robertson, J.L.; Barling, J. Greening organizations through leaders' influence on employees' pro-environmental behaviors. J. Organ. Behav. 2013, 34, 176-194. [CrossRef]

30. Robertson, J.L.; Barling, J. Contrasting the nature and effects of environmentally specific and general transformational leadership. Leadersh. Organ. Dev. J. 2017, 38, 22-41. [CrossRef]

31. Hartmann, M. Corporate social responsibility in the food sector. Eur. Rev. Agric. Econ. 2011, 38, 297-324. [CrossRef]

32. Huang, S.Y.B.; Lee, S.-C.; Lee, Y.-S. Why can green social responsibility drive agricultural technology manufacturing company to do good things? A novel adoption model of environmental strategy. Agronomy 2021, 11, 1673. [CrossRef]

33. Lee, C.-J.; Huang, S.Y. A moderated mediation examination of Kahn's theory in the development of new product performance: Cross-level moderating role of open discussion of conflict. Chin. Manag. Stud. 2019, 13, 603-615. [CrossRef]

34. Sheehy, B. Defining CSR: Problems and solutions. J. Bus. Ethics 2015, 131, 625-648. [CrossRef]

35. Rahman, N.; Post, C. Measurement issues in environmental corporate social responsibility (ECSR): Toward a transparent, reliable, and construct valid instrument. J. Bus. Ethics 2012, 105, 307-319. [CrossRef]

36. Waldman, D.A.; Siegel, D.S.; Javidan, M. Components of CEO transformational leadership and corporate social responsibility. J. Manag. Stud. 2006, 43, 1703-1725. [CrossRef]

37. Iqbal, S.; Farid, T.; Ma, J.; Khattak, A.; Nurunnabi, M. The impact of authentic leadership on organizational citizenship behaviours and the mediating role of corporate social responsibility in the banking sector of Pakistan. Sustainability 2018, 10, 2170. [CrossRef]

38. Kim, M.-S.; Thapa, B. Relationship of ethical leadership, corporate social responsibility and organizational performance. Sustainability 2018, 10, 447. [CrossRef]

39. Chen, Y.; Tang, G.; Cooke, F.L.; Jin, J. How does executive strategic resource management link to organizational ambidexterity? An empirical examination of manufacturing firms in China. Hum. Resour. Manag. 2016, 55, 919-943. [CrossRef]

40. Saleem, M.; Qadeer, F.; Mahmood, F.; Ariza-Montes, A.; Han, H. Ethical leadership and employee green behavior: A multilevel moderated mediation analysis. Sustainability 2020, 12, 3314. [CrossRef]

41. Mahmood, F.; Qadeer, F.; Abbas, Z.; Hussain, I.; Saleem, M.; Hussain, A.; Aman, J. Corporate social responsibility and employees' negative behaviors under abusive supervision: A multilevel insight. Sustainability 2020, 12, 2647. [CrossRef]

42. Muralidharan, E.; Pathak, S. Sustainability, transformational leadership, and social entrepreneurship. Sustainability 2018, 10, 567. [CrossRef]

43. Kozlowski, S.W.J.; Klein, K.J. A multilevel approach to theory and research in organizations: Contextual, temporal, and emergent processes. In Multilevel Theory, Research, and Methods in Organizations: Foundations, Extensions, and New Directions; Klein, K.J., Kozlowski, S.W.J., Eds.; Jossey-Bass: San Francisco, CA, USA, 2000; pp. 3-90.

44. Cappelli, P.; Sherer, P.D. The missing role of context in OB: The need for a meso-level approach. In Research in Organizational Behavior; Cummings, L.L., Staw, B.M., Eds.; JAI Press: Greenwich, CT, USA, 1991; pp. 55-110.

45. Bandura, A. Social Foundations of Thought and Action: A Social Cognitive Theory; Prentice-Hall: Englewood Cliffs, NJ, USA, 1986.

46. Chen, G.; Kanfer, R. Toward a systems theory of motivated behavior in work team. In Research in Organizational Behavior; Staw, B.M., Ed.; JAI Press: Greenwich, CT, USA, 2006; pp. 349-381.

47. Huang, S.Y.B.; Lee, S.-C.; Lee, Y.-S. Constructing an adoption model of proactive environmental strategy: A novel quantitative method of the multi-level growth curve model. Mathematics 2021, 9, 1962. [CrossRef]

48. Huang, S.; Ting, C.-W.; Fei, Y.-M. A multilevel model of environmentally specific social identity in predicting environmental strategies: Evidence from technology manufacturing businesses. Sustainability 2021, 13, 4567. [CrossRef]

49. James, L.R.; Demaree, R.G.; Wolf, G. Estimating within-group interrater reliability with and without response bias. J. Appl. Psychol. 1984, 69, 85-98. [CrossRef]

50. Fornell, C.; Lacker, D.F. Evaluating structural equation models with unobservable variables and measurement error. J. Mark. Res. 1981, 18, 39-50. [CrossRef]

51. Vlachos, P.A.; Panagopoulos, N.G.; Rapp, A.A. Employee judgments of and behaviors toward corporate social responsibility: A multi-study investigation of direct, cascading, and moderating effects. J. Organ. Behav. 2014, 35, 990-1017. [CrossRef]

52. Aguinis, H.; Glavas, A. What we know and don't know about corporate social responsibility. J. Manag. 2012, 38, 932-968. [CrossRef]

53. Sheehy, B.; Farneti, F. Corporate social responsibility, sustainability, sustainable development and corporate sustainability: What is the difference, and does it matter? Sustainability 2021, 13, 5965. [CrossRef]

54. Huang, S.Y.B.; Li, M.-W.; Chang, T.-W. Transformational leadership, ethical leadership, and participative leadership in predicting counterproductive work behaviors: Evidence from financial technology firms. Front. Psychol. 2021, 12. [CrossRef]

55. Huang, S.Y.B.; Li, M.-W.; Lee, Y.-S. Why do medium-sized technology farms adopt environmental innovation? The mediating role of pro-environmental behaviors. Horticulturae 2021, 7, 318. [CrossRef] 